\title{
HNRNPA3 wt Allele
}

National Cancer Institute

\section{Source}

National Cancer Institute. HNRNPA3 wt Allele. NCI Thesaurus. Code C54413.

Human HNRNPA3 wild-type allele is located in the vicinity of 2 q31.2 and is approximately $6 \mathrm{~kb}$ in length. This allele, which encodes heterogeneous nuclear ribonucleoprotein $A 3$, is involved in the regulation of cytoplasmic RNA trafficking. 